\title{
QUALITY ASSESMENT OF SPOT MOUNDS MADE WITH ROTATING MOUNDER UOT M22
}

Karlis Dumins, Toms Stals, Dagnija Lazdina

Latvian State Forest Research Institute "Silava", Latvia

karlis.dumins@silava.lv, toms.stals@silava.lv,dagnija.lazdina@silava.lv

\begin{abstract}
Choosing the most suitable soil preparation method is not only important in aspects of seedling growth conditions, but it is also a question about costs of forest regeneration. Most popular soil preparation methods in Latvia are either furrows with disc trenching or spot mounds with an excavator on soils with unfavourable water regime for optimal seedling environment. As modern technology evolves, mounders installed on forwarders become more sophisticated and well adapted to difficult conditions. The main advantage of mounders installed on forwarders is better productivity and lower costs for forest renewal compared to spot mounds made with the excavator bucket. The aim of this study is to asses a two arm UOT MOUNDER M22 compliance with the established quality standards in the Latvia State Forests and compare the soil preparation quality with LSFRI Silava elaborated excavator bucket MPV600 and a mounding/planting device M-planter. The study of UOT MOUNDER M22 was done in the eastern part of Latvia, where in 5 clear cuts soil was prepared with the two arm UOT MOUNDER M22 in 2017 and reforested in 2018, and 5 clear cuts, where soil was freshly prepared in spring of 2018, collecting data with the mound dimensions and count of planting spots prepared in clear cut. The results of this study show that with UOT MOUNDER M22 it is possible to make $3822 \pm 106$ planting spots per hectare in typical clear cuts in Latvia, total compliance with soil preparation quality requirements is $50.6 \%$.
\end{abstract}

Keywords: UOT M22, forest regeneration, soil preparation, forestry.

\section{Introduction}

In Latvia, the most popular forest soil preparation method is disc trenching, however, from spot mounding reintroduction in forestry in the early 2010s the territory where this method has been used gradually increases. The reason for this is that spot mounding is more suitable in harsh environmental conditions - in very wet forest sites, because the mound pit collects excessive water. Mounding also could decrease how many early tendings need to be applied, and also decrease damage caused by pine weevils [1] and promote tree growth and surviving [2]. And from 2017, in the Latvia State Forest managed lands one new technical unit is used for soil preparation - the rotating mounder UOT M22 and this device combines aspects of the disc trencher and the excavator mounder.

The principle of rotating mounders are rotating steel blades which stop and gather living plant layer, ground litter and upper soil layer, invert it and press the gathered material and after that keep rotating. In the result, there is a pit - scarified patch and spot mound with mineral or organic soil layer on the top [3]. It is possible in mineral and organic soil with this kind of machine to prepare $15-20 \mathrm{~cm}$ high mound, but in poor sandy soils these mounders create $5-10 \mathrm{~cm}$ high mound [4]. The mound upper layer should be covered with $5-10 \mathrm{~cm}$ thick mineral soil layer for plant protection against Hylobius abietis and also the mineral layer provides a sufficient water regime for tree roots, if there is not left deadwood, for example, branches or other larger objects between the mound and ground litter [5].

First rotating mounders in forestry were implemented between 1970 and 1980 in Sweden and Canada [1]. In the USSR, including the territory of Latvia, the first prototypes also appeared during this period. Technologies have been improving and nowadays it is possible to prepare soil with rotating mounders in quite harsh environment and these machines have become more cost-efficient. Nowadays, rotating mounders are equipped with hydraulic systems and simultaneously are preparing two to four lines with mounds and it is possible to regulate different parameters for these lanes [6]. It combines the positive aspects from disc trenching and mounding with an excavator, and these are efficiency, planting spot distribution in the forest stand and benefits of spot mounds.

The limiting factors for applying this soil preparation method is the soil bearing capacity, weight and off-road performance of towing machines. The main obstacles for the rotating mounder are felling residuals, high stumps, rocks and other leftovers after felling [7]. In Finland, scientists have analysed a rotating mounder Bräcke M25 and a mounder BD 296 in 124 hectares and divided the created mounds in two groups: appropriate and inappropriate planting spots. By Finland legislation, there have to be at least 1600 planting spots in one hectare. The result that they gained was that in their environmental conditions it is possible to create $1892 \pm 290$ planting spots, of which $1398 \pm 325$ (74\%) had 
sufficient quality [3]. Other authors suggest that it is possible to create $1430 \pm 460$ good quality mounds in one hectare of forest land. In this publication it is also mentioned that removal of slash increases the amount of good quality planting spots [5]. Another research suggests that every 100 high stumps decrease the possibility to create good planting spots by $1.5 \%$ [8]. If soil preparation is conducted when felling residues had started to decay, then it is possible to gain more sufficient quality planting spots [3], or if the residues of felling have been removed, then the amount of good quality mounds can increase by $20 \%$ [9].

Combining all factors together, in practical forestry could be situation that there are not enough planting spots, then using this kind of soil preparation method, it is also acceptable to plant trees in scarified pit/patch, but this can serve only as a backup variant, because trees planted on mounds grow better and have a higher chance of survival [10].

From productivity and cost efficiency point of view rotating mounders are more efficient compared to classical mounding, exception is in very small forest stands. With rotating mounders it is possible to prepare soil three times faster than with an excavator [7].

In Latvia, average soil preparation service costs for disc trenching are 120-180 EUR $\cdot \mathrm{ha}^{-1}$ and mounding with an excavator 450-550 EUR $\cdot \mathrm{ha}^{-1}$ [11]; and the research carried out in Finland shows that the rotating mounder can be approximately three times more cost efficient than the excavator mounding [12], and if in Latvia proportional cost difference would be the same, then soil preparation costs with the disc trencher and rotating mounder should be similar.

The aim of this study is to assess the two arm UOT MOUNDER M22 compliance with the established quality standards in the Latvia State Forests and compare the soil preparation quality with LSFRI elaborated excavator bucket MPV600 and the mounding/planting device M-planter.

\section{Materials and methods}

This study data were analysed from 16 forest clear cuts in the central and eastern part of Latvia, Fig. 1. The data about UOT M22 mounder were compared with the soil preparation quality standards of the Latvia State Forests and with mounds made with the excavator bucket MPV-600 and with the soil preparation and planting device M-Planter. Data about mounds made with UOT were collected in the fall of 2018, in five study sites soil was prepared in spring of 2017 and reforested in the spring of 2018 , but in the other five study sites only soil was prepared in spring of 2018, whereas data about mounds made with MPV-600 and M-Planter were collected in the fall of 2017 and 2018 after one and two vegetation seasons. Research was done in various mesotrophic and eutrophic forests.

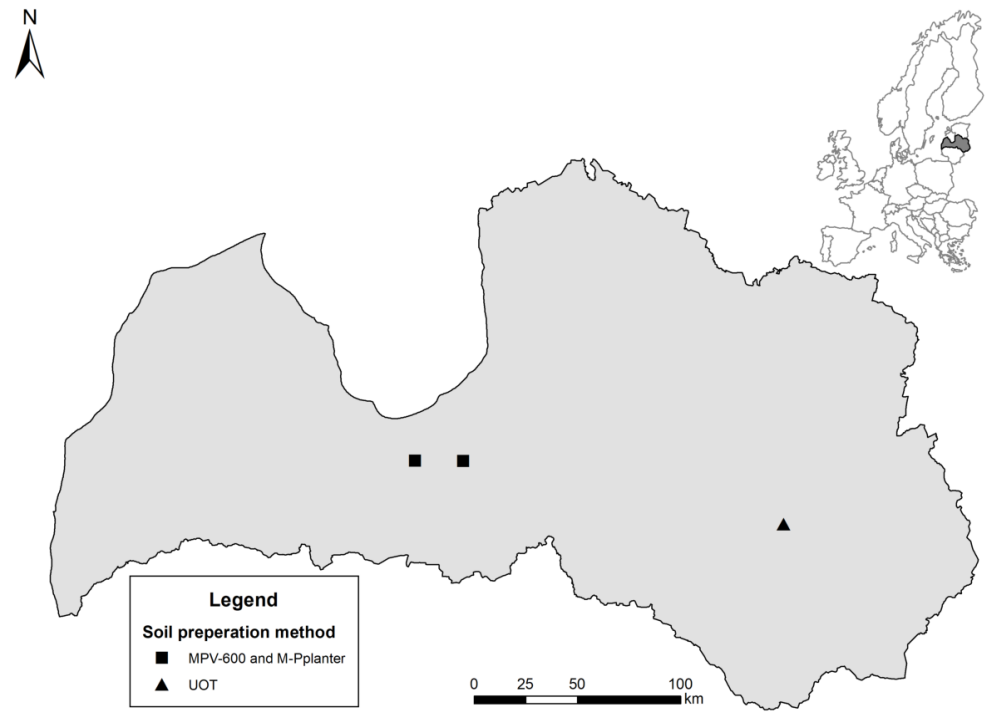

Fig. 1. Locations of study sites

In each study site five evenly distributed sample plots were created. For mounds made with MPV-600 and M-Planter sample plots were circular with the radius $2.82 \mathrm{~m}\left(A=25 \mathrm{~m}^{2}\right)$, whereas for the UOT mounder each sample plot was 10 meters long including both lines with mounds, and the 
distance between the mounds was measured and the area of plot calculated, Fig. 2. The plot size for UOT M22 varied from $24.56 \mathrm{~m}^{2}$ to $30 \mathrm{~m}^{2}$. Mound dimensions were measured and mounds were counted in the study plots and planting spot density calculated per hectare.

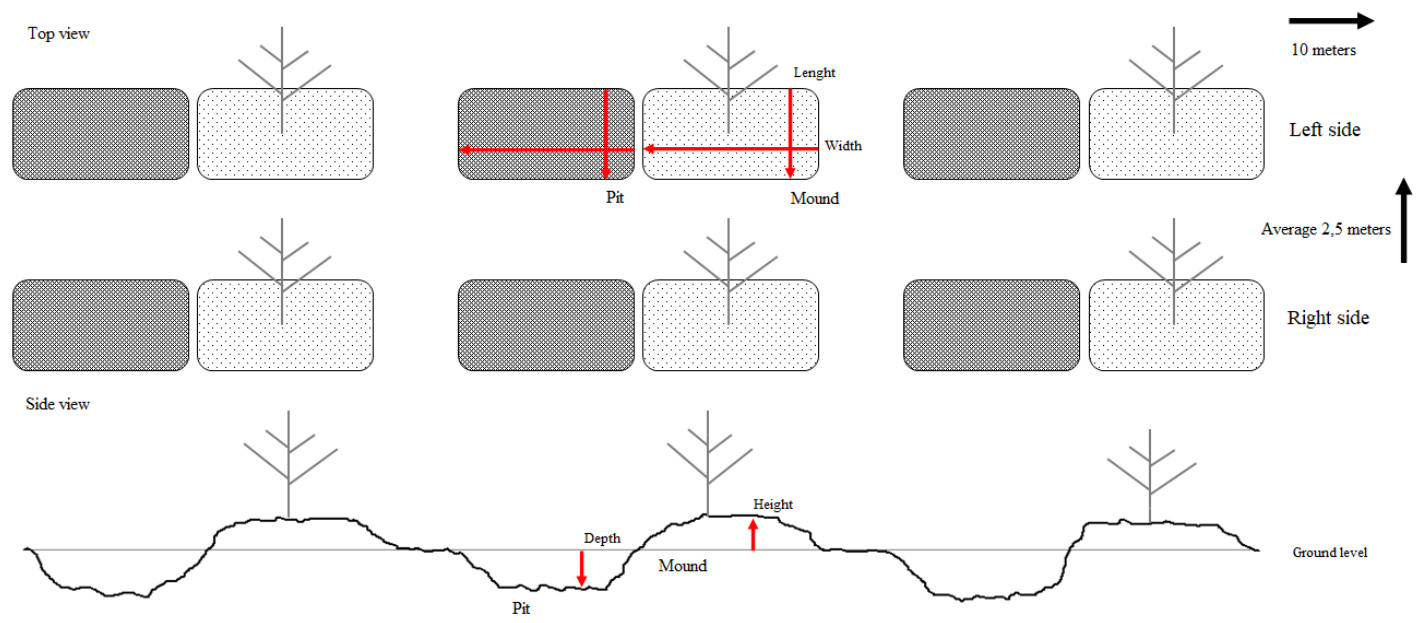

Fig. 2. Schematic illustration of mound placement and measures

For mound dimensions the mean height, width and length and standard deviation (SD) were calculated. Lavene's test was applied to assess the equality of variances of the mound parameter data and Shapiro-Wilks test was used to assess normality of data. The data for all three mound dimensions were not normally distributed, therefore nonparametric Kruskal-Wallis $\mathrm{H}$ test and followed Wilcoxon rank sum test were used to determine, if there is significant difference between the soil preparation methods. Also, for each soil preparation method the mean density of planting spots and the proportion of good quality spots were calculated. From these data the density of sufficient planting spots for each soil preparation method was calculated after one and two vegetation seasons.

\section{Results and discussion}

The mound dimension parameters significantly $(p<0.05)$ differ between the soil preparation methods with one exemption - average mound height difference after two vegetation seasons between the M-planter and UOT M22 was not significant. Mound average height after one vegetation season was higher where UOT M22 was used, but the average mound width and length was the largest where MPV-600 was used. After two vegetation seasons the average mound height differences between the methods are declining, Table 1.

Mean mound parameters and standard deviation one and two vegetation seasons after soil preparation

Table 1

\begin{tabular}{|c|c|c|c|c|}
\hline $\begin{array}{c}\text { Vegetation } \\
\text { season }\end{array}$ & Device used & Height, cm & Width, cm & Length, cm \\
\hline First & UOT M22 & $22.3 \pm 6.1$ & $56.3 \pm 18.7$ & $67.1 \pm 12.7$ \\
\hline First & MPV-600 & $17 \pm 5.3$ & $91.5 \pm 15.9$ & $92.1 \pm 18.7$ \\
\hline First & M-planter & $15.6 \pm 4.5$ & $83.8 \pm 14.4$ & $85.4 \pm 15.7$ \\
\hline Second & UOT M22 & $14.2 \pm 5.7$ & $88.1 \pm 14.1$ & $72.3 \pm 12.1$ \\
\hline Second & MPV-600 & $15.6 \pm 5.1$ & $94.4 \pm 16$ & $90.6 \pm 16.8$ \\
\hline Second & M-planter & $14.1 \pm 5$ & $88.1 \pm 14.1$ & $83.5 \pm 16.2$ \\
\hline
\end{tabular}

After one vegetation season at least half of mounds regardless of the device used are higher than the standard determined by the Latvia State Forests [13]. As described by other authors, it is possible with a rotating mounder to prepare at least $15-20 \mathrm{~cm}$ high mounds [4]. The mound height over time period decreases regardless of the soil preparation device used, Fig. 3. 


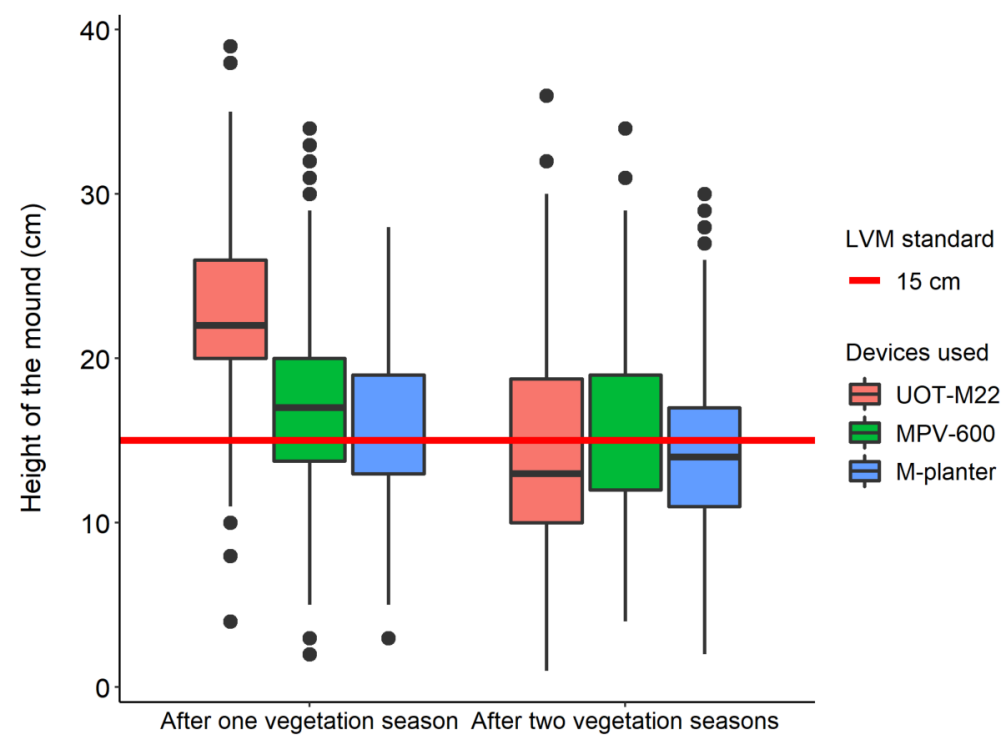

Fig. 3. Mound height after one and two vegetation seasons depending on the device used and their relevance to the Latvia State Forest (LVM) standard for minimal mound height (*outliers of data marked as black spots)

After one and also two vegetation seasons, the width of all mounds prepared with MPV-600 and M-planter met the Latvia State Forest requirements. More than half of the mounds made with the rotating mounder also fulfilled the width requirements, Fig. 4. Unlike the height, the mound width and length over time period slightly increase, Fig. 4, Fig. 5.

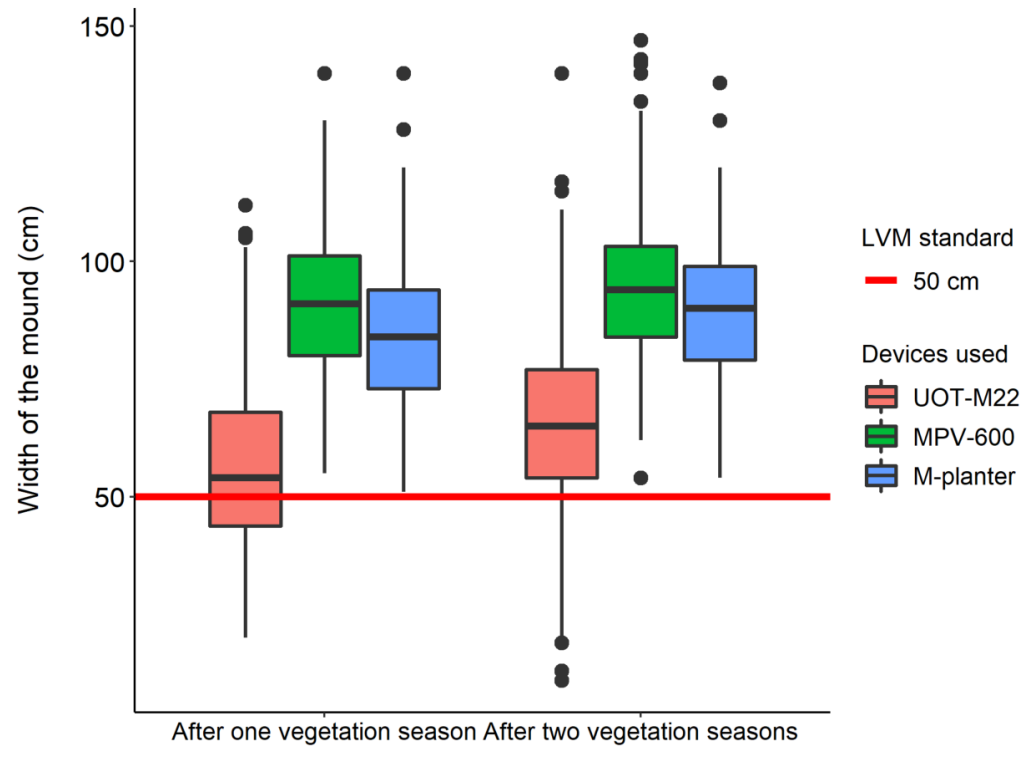

Fig. 4. Mound width after one and two vegetation seasons depending on the device used and their relevance to the Latvia State Forest (LVM) standard for minimal mound width (*outliers of data marked as black spots)

After one and also two vegetation seasons, the length of almost all mounds prepared with MPV600 and M-planter met the Latvia State Forest requirements. At least three-quarters of the mounds made with the rotating mounder also fulfilled the length requirements, Fig. 5.

Total mound density in one theoretical hectare differed by the device used in soil preparation and also the proportion of good planting spots differed. It is possible with the rotating mounder UOT M22 create more planting spots per ha than with the two other devices. The proportional amount of good quality planting spots is lower for this device, but despite of that, in one hectare prepared with UOT M22 there will be more good quality planting spots. 


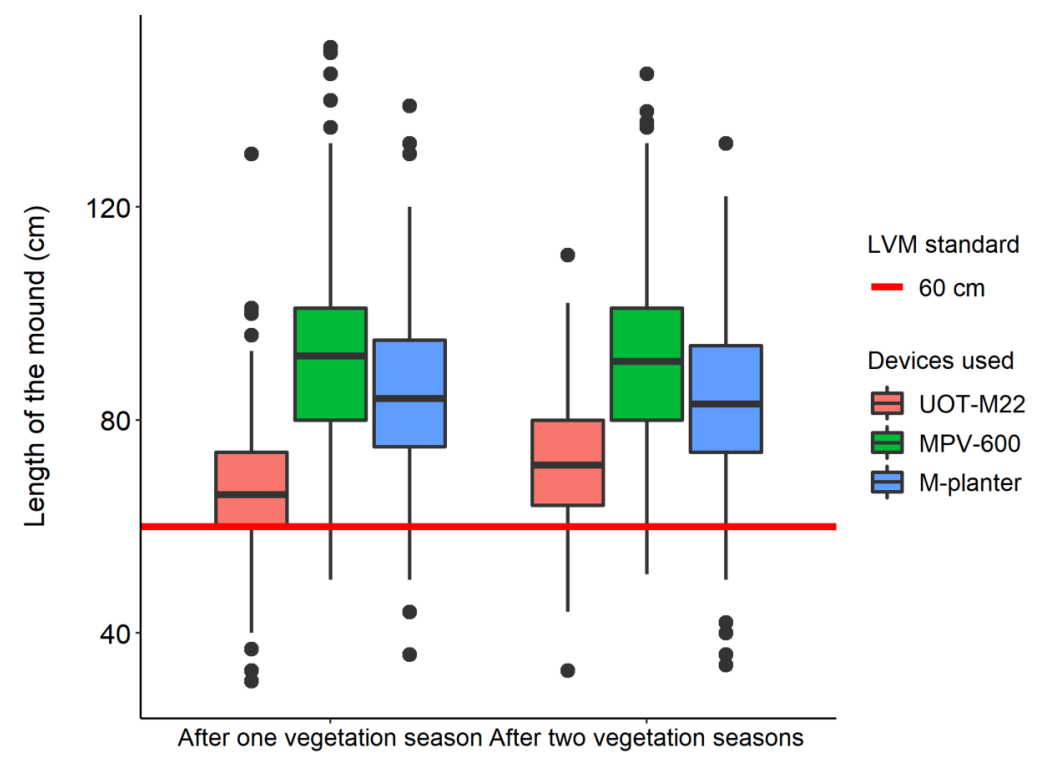

Fig. 5. Mound length after one and two vegetation seasons depending on the device used and their relevance to the Latvia State Forest (LVM) standard for minimal mound length (*outliers of data marked as black spots)

In our research we estimated that under Latvian forest conditions it is possible to create $3822 \pm 106$ planting spots with UOT M22, of which around $50.6 \%$ are with sufficient quality and that provides nearly two thousands of planting spots Table 2 and that is more than the requirement of planting spots in Finland [3]; and overall our results suggest that with UOT M22 it is possible to prepare more planting spots in one hectare compared to other rotating mounders $[3 ; 7]$, at least in forest conditions as in Latvia.

Table 2

Total average \pm SEM density of planting spots and density of good quality planting spots one and two vegetation seasons after soil preparation with different devices used

\begin{tabular}{|c|c|c|c|c|}
\hline $\begin{array}{c}\text { Vegetation } \\
\text { seasons after }\end{array}$ & Device used & $\begin{array}{c}\text { Density of spots } \\
\text { (mounds) } \mathbf{h a}^{-1}\end{array}$ & $\begin{array}{c}\text { \% good quality } \\
\text { spots }\end{array}$ & $\begin{array}{c}\text { Density of good } \\
\text { quality spots } \\
\text { (mounds) } \mathbf{~ h a}^{-1}\end{array}$ \\
\hline One & UOT M22 & $3822 \pm 106$ & 50.6 & $1930 \pm 151.2$ \\
\hline One & MPV-600 & $2213 \pm 91$ & 69.8 & $1533 \pm 70.6$ \\
\hline One & M-planter & $2193 \pm 77.6$ & 61.3 & $1319 \pm 281.7$ \\
\hline Two & UOT M22 & $3634 \pm 110.9$ & 36.7 & $1260 \pm 72.7$ \\
\hline Two & MPV-600 & $2187 \pm 53.5$ & 58 & $933 \pm 84.9$ \\
\hline Two & M-planter & $2220 \pm 60.8$ & 42.4 & $1347 \pm 77.6$ \\
\hline
\end{tabular}

As described by other authors, the main cause of insufficient quality planting spots are large roots, high stumps and felling residues left in the forest stand after clear felling [3;8;9]. These factors also explain the considerable variations of mound dimensions. And comparing bucket mounding with the rotating mounder, this method provides more favourable conditions for early tending [14].

\section{Conclusions}

1. The rotating mounder UOT M22 provides sufficient soil preparation results and $50.6 \%$ of planting spots compile the quality requirements. The UOT M22 mounder can be used as an alternative soil preparation method/device.

2. With UOT M22 it is possible to prepare more planting spots (3822 in one hectare) than using the technique of excavator bucket mounding (around 2200 planting spots in one hectare). UOT M22 combines productivity of disc trenching and benefits of spot mounding. 


\section{Acknowledgements}

This study was part of the JSC "Latvia State Forest" research program "Forest regeneration, establishment, tending and thinning program 2016-2020 [5-5.5_000p_101_16_22]".

\section{References}

[1] Sutton R. F. Mounding site preparation: a review of European and North American experience. New forests, 1993, 7.2: 151-192.

[2] Celma S., Blate K., Lazdina D., Dūmiņš K., Neimane S., Štāls T. A., Štikāne K. Effect of soil preparation method on root development of P. sylvestris and P. abies saplings in commercial forest stands. New Forests, 2019, 1-1.

[3] Saksa T., Miina J., Haatainen H., Kärkkäinen K. Quality of spot mounding performed by continuously advancing mounders. Silva Fennica, 2018, 52(2).

[4] Luoranen J., Saksa T., Finér L., Tamminen P. Metsämaan muokkausopas (Forest Soil Modification Guide). Gummerus Kirjapaino Oy, 2007. (In Finnish)

[5] Örlander, G., Nilsson, U. Effect of reforestation methods on pine weevil (Hylobius abietis) damage and seedling survival. Scandinavian journal of forest research, 1999, 14(4), 341-354.

[6] Löf M., Ersson B. T., Hjältén J., Nordfjell T., Oliet J. A., Willoughby I. Site preparation techniques for forest restoration. Restoration of boreal and temperate forests. CRC Press, Baco Raton, 2015, 85-102.

[7] Rantala J., Saarinen V. M., Hallongren H. Quality, productivity and costs of spot mounding after slash and stump removal. Scandinavian Journal of Forest Research, 2010, 25(6), 507-514.

[8] Andersson G., Brunberg T. Productivity norms for vehicle-mounted mounders. RedogoerelseForskningsstiftelsen Skogsarbeten, 1991.

[9] Saarinen V. M. The effects of slash and stump removal on productivity and quality of forest regeneration operations-preliminary results. Biomass and Bioenergy, 2006, 30(4), 349-356.

[10] Hallsby G., Örlander G. A comparison of mounding and inverting to establish Norway spruce on podzolic soils in Sweden. Forestry, 77(2), 2004, 107-117.

[11]Lazdina D. Meža atjaunošanas, ieaudzēšanas un kopšanas programma. Pārskats par pētījuma 2017. gada rezultātiem (The forest regeneration, establishment and cleaning research program. Overview of the results from 2017). [online] [23.03.2020]. Available at: https://www.lvm.lv/images/lvm/LVM_petijumi_un_publikacijas/2018.03.07/atjaunosana_2017.pd f. (In Latvian)

[12] Hallongren H., Laine T., Rantala J., Saarinen V. M., Strandström M., Hämäläinen J., Poikela A. Competitiveness of mechanized tree planting in Finland. Scandinavian Journal of Forest Research, 2014, 29(2), 144-151.

[13] Kvalitātes prasības augsnes gatavošanas darbu izpildei, veidojot pacilas (Quality requirements for soil preparation with mounding). [online] [17.03.2020]. Available at: https://www.lvm.lv/images/lvm/kvalitates_prasiba_augsnes_gatavosanai_ar_pacilu_metodi_2019. 05.17.pdf (In Latvian)

[14] Makovskis K., Lazdina D., Kaleja S., Spalva G., Dumins K. Planting and tending productivity comparison in mounds and disc trenches using containerized and bareroot coniferous seedlings. Agronomy Research, vol. 17(6), 2019, pp. 2327-2338. 